\title{
Spina Bifida Cystica Families X-Ray Examination and HLA Typing
}

\author{
J. P. VANNIER, ${ }^{113,15}$ J. LEFORT, B. CAVELIER, P. LEDOSSEUR, C. ASSAILLY, AND J. FEINGOLD \\ Centre Régional de Transfusion Sanguine. B.P. $n^{\circ} 5$ (Directeur: Docteur C. Ropartz). 76230-Bois-Guillaume (J. P. V., \\ B. C.]; Service de Chirurgie Pédiatrique (Professeur Borde), Hopital Charles-Nicolle, 76000-Rouen [J. L.J; Service de \\ Radiologie (Professeur Benozio). Hopital Charles-Nicolle. 76000-Rouen (P. L., C. A.J; INSERM U.155. Château de \\ Longchamp. Bois de Boulogne. 75016-Paris, France [J. F.]
}

\begin{abstract}
Summary
Thirty-three families of individuals with a history of spina bifida with myelomeningocele were studied. Each member was HLA typed and had a spinal X-ray. The incidence of spina bifida occulta and laminal asymmetry of the lumbo-sacral spine in sibs and parents is high. No association between these abnormalities and the HLA system was found.
\end{abstract}

Spina bifida cystica with myelomeningocele is one of the most frequent and severe congenital malformations of the spinal cord. The etiology of this condition is still unknown.

The recurrence risk of this malformation is high in sibs $(3 \%$ from a review study) (10). The recurrence risk rises as the number of affected sibs and the population incidence increase, but in general is lower than $25 \%$. In parents of affected children, there is a high incidence of spina bifida occulta (7). Amos et al. (1) have described a large family with 98 members in whom they found an inherited association of spina bifida occulta and vertebral joint facet asymmetry, which they ascribed to a single locus. This locus would be on chromosome 6 at about 30 centimorgans distance from the HLA group of loci.

A human equivalent of the T-locus of the mouse has been looked for, and there is suggestive, albeit circumstantial evidence for this in man (4). The T-locus complex in the mouse is located on chromosome 17, at about 12 to 14 centimorgans from the centromere. It is linked to the H-2 complex and is the site of a great number of mutations, some of which are responsible for tail and vertebral abnormalities. Sperm production, genetic recombination and other aspects of embryonic development are sometimes affected by some specific mutations of the T-locus.

In an earlier study, we performed HLA, Pi (alpha-1-antitrypsin), $\mathrm{Gm}$, and $\mathrm{Km}$ (immunoglobulins) typing in 53 spina bifida cystica cases (11). The present study looks for an association between HLA haplotypes and spinal abnormalities, especially spina bifida occulta and laminal asymmetry.

\section{MATERIALS AND METHODS}

For 8 years, 146 children with spina bifida cystica have been treated by the pediatric surgical service of Rouen. A study of both parents was possible in 33 families, of only one parent in 14 families, of sibs in 40 families, and of relatives such as aunts, uncles, and grandparents in 19 families. The objective and limits of our study had been explained to each subject. Most of them permitted a venepuncture and an anteroposterior X-ray examination of the lumbosacral spine.

Complete red-blood-cell, $\mathrm{Gm}$ and $\mathrm{Km}, \mathrm{Pi}$ and HLA haplotypes were ascertained. HLA determination was accomplished by the microlymphocytotoxicity technique with local and national re- agents. HLA haplotypes were determined by family studies. Lumbosacral X-rays of relatives were read by two radiologists. Only spina bifida occulta and vertebral laminal asymmetry were considered to be abnormal for the purposes for this study. The first abnormality is defined as an absence of fusion of each half of the posterior vertebral arch; the second is the result of an asymmetric fusion of these arches (Fig. 1). It should be remembered that each lateral half of the vertebral arch originates from a separate centre of ossification. They fuse during the first year of life in the lumbar vertebrae (5).

The average incidence of these abnormalities was determined in two control studies. The first study was of 299 adult patients who had an X-ray examination for other pathologic reasons, and the second was of 178 children who had an X-ray examination for abdominal pain.

\section{RESULTS}

In the adult study, the incidence of lumbo-sacral vertebral lesions, as defined above, was higher in males $(27.9 \%)$ than in females $(16.9 \%)$. The difference is significant $(P<0.05)$ (Table 1 ).

In the children studied, there was neither a significant variation in the incidence between youngest and oldest nor between males and females (Table 2).

The frequency of spina bifida occulta, with or without laminal asymmetry, was higher in children $(27.5 \%)$ than in adults $(10.4 \%)$ but the frequency of laminal asymmetry was lower (5 and $14.4 \%$, respectively).

The incidence of these abnormalities in sibs of spina bifida cystica individuals is $53 \%$ and in parents $47.3 \%$. When this was compared to the frequencies found in the two control populations, the differences were significant $(P<0.01$ and $P<0.001$, respectively) (Table 4).

In second degree relatives, a moderate increase in frequency was noted in aunts and uncles, but no variation was seen in the small number of grandparents studied (Table 4).

The situation is quite similar for the two types of vertebral abnormalities, i.e., spina bifida occulta and laminal asymmetry. In 33 families, we have observed the following different distributions of anomalies:

in 17 families, one parent had a vertebral abnormality;

in 8 families, there was no vertebral lesion in the parents:

in 8 families, both parents had at least one lesion and: in two, a sib had a normal neural tube;

in three, all sibs had a vertebral abnormality; in three, the propositus had no sib.

HLA antigen frequencies in propositi (spina bifida cystica) are reported in Table 4. HLA-A9 and HLA-B5 antigen frequencies are increased. It is noteworthy that HLA-B27 is decreased. 


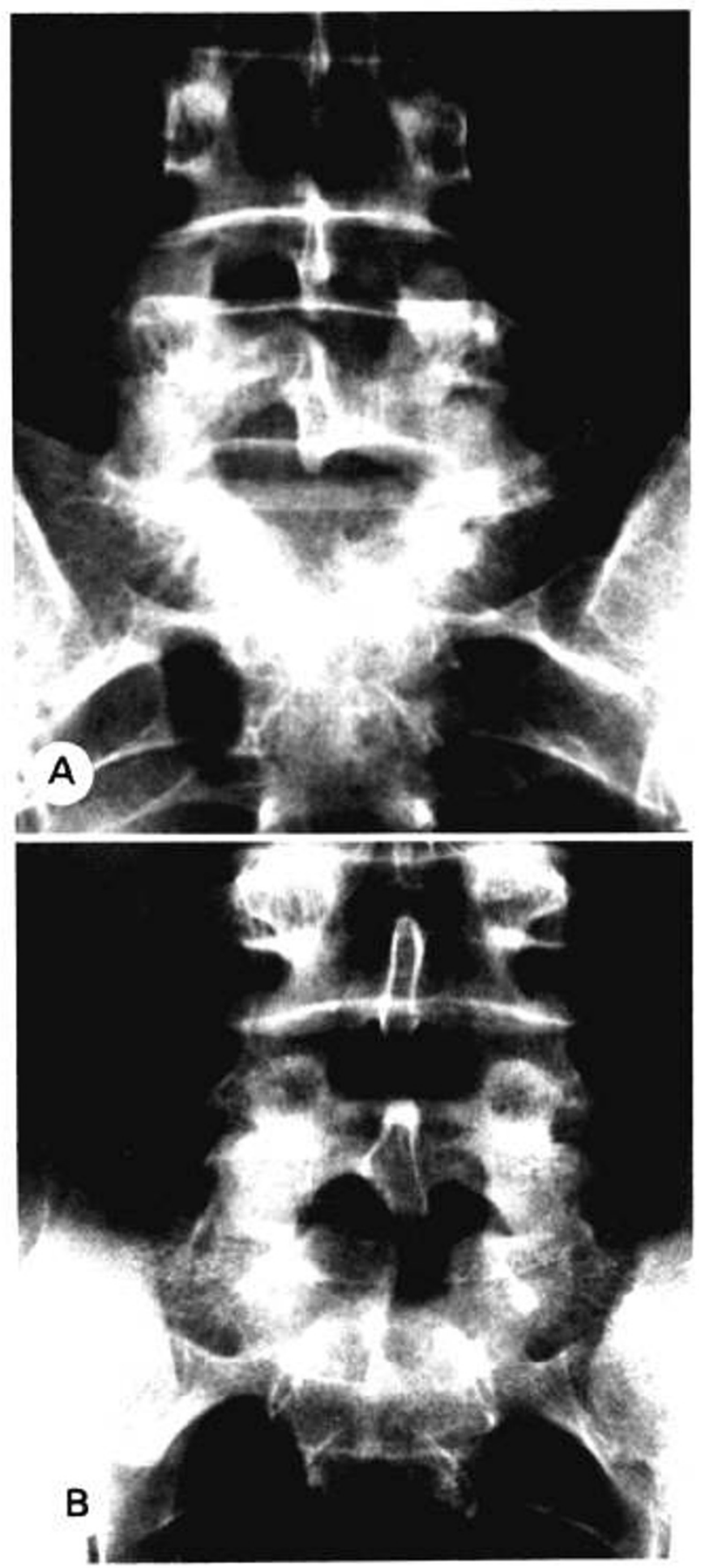

Fig. 1. $A$, laminal asymmetry (L5); $B$, spina bifida occulta (S1).

Table 5 shows HLA phenotypes in sibs. Parental haplotype segregation and X-ray examination are reported in Table 3.

There is no significant difference between paternal and maternal haplotype distribution in sibs with or without vertebral abnormalities (Table 6).

\section{DISCUSSION}

In our study, the frequency of spina bifida occulta (with or without laminal asymmetry) in adults $(10.4 \%)$ is lower than that reported by R. H. Post (9), which was near $25 \%$ (L5 and $\mathrm{S} 1$ ), varying from 3.6 to $48 \%$.
Such variations are probably related to ethnic differences, but also to the methods of detection; we did not take into account cervical and dorsal lesions, and these are frequent (9).

The incidence of lumbosacral spina bifida occulta is higher in children than in adults. Some cases of spina bifida occulta probably disappear by fusion after the age of sixteen.

Vertebral laminal asymmetry seems to be correlated with spina bifida occulta. Its frequency increases in our adult controls, whereas spina bifida occulta frequency decreases, and they have the same localization; these facts could suggest that the laminal asymmetry could be the result of an asymmetrical fusion of the posterior arches.

The frequency of lumbosacral vertebral lesions is lower in adult females than in males. The sex ratio is near unity before the age of sixteen. A symmetrical fusion may be more frequent in females. Wynne-Davies found a female preponderance of nearly $3: 1$ for patients with multiple vertebral abnormalities, with or without spina bifida (occulta or cystica), and a 3:2 female preponderance for solitary vertebral abnormalities such as hemivertebrae, anterior body defects, narrowing of disc spaces or fused vertebrae (12).

In a study in Glasgow, Richards et al. (10) found a male:female sex ratio near 4:5 for spina bifida cystica, but Lorber and Levick (7) in a survey of parents of children with spina bifida cystica, showed an excess of fathers with spina bifida occulta. The male: female sex ratio for parents with spina bifida occulta is approximately $2: 1$ and was of the same order for his control population.

It seems, therefore, that the male:female sex ratio is above unity for minor vertebral abnormalities such as spina bifida occulta or laminal asymmetry and under unity for the more severe abnormalities (e.g., spina bifida cystica or multiple vertebral lesions).

In our study, we have found a high frequency of low spinal lesions in families with cases of spina bifida cystica. These findings agree with the results of Lorber et al. (7) and suggest a partial common heredity for these lesions.

The high recurrence risk of spina bifida cystica in sibs is consistent with the existence of genetic factors in the aetiology of this condition. Some of them are probably common with spina bifida occulta, as seen above. However, the different sex ratios suggest genetic differences.

Table 1. Lumbo-sacral spina bifida occulta, laminal asymmetry, and their lumbar or sacral localization in 299 adult controls undergoing $X$-rays for other pathological conditions

\begin{tabular}{|c|c|c|c|c|c|c|c|}
\hline & Localization & & $\begin{array}{l}\text { males } \\
=130) \\
\end{array}$ & & $\begin{array}{l}\text { Iales } \\
=169)\end{array}$ & & $\begin{array}{l}\text { otal } \\
=299) \\
\end{array}$ \\
\hline & L5-SI & 1 & & 1 & & 2 & \\
\hline \multirow[t]{5}{*}{ S.O. ${ }^{1}$} & S1 & 8 & & 14 & & 22 & \\
\hline & S1-S2 & 0 & & 1 & & 1 & \\
\hline & S.O. total & 9 & $(6.9)^{2}$ & 16 & $(9.4)$ & 25 & (8.4) \\
\hline & L4-L5 & 1 & & 1 & & 2 & \\
\hline & L5 & 2 & & 6 & & 8 & \\
\hline \multirow[t]{4}{*}{ L.A. } & L5-S1 & 0 & & 2 & & 2 & \\
\hline & SI & 8 & & 17 & & 25 & \\
\hline & L.A. total & 11 & $(8.5)$ & 26 & $(15.4)$ & 37 & $(12.4$ \\
\hline & $\begin{array}{l}\text { L4-LS (L.A.) + S1 } \\
\quad \text { (S.O.) }\end{array}$ & 1 & & 1 & & 2 & \\
\hline $\begin{array}{r}\text { S.O. } \\
+\end{array}$ & $\begin{array}{l}\text { L5 (L.A.) }+ \text { S1 } \\
\text { (S.O.) }\end{array}$ & 1 & & 1 & & 2 & \\
\hline \multirow[t]{3}{*}{ L.A. } & $\underset{\text { S.O-S1 }}{\text { S.O.) }}+$ (L.A. + & 0 & & 1 & & 1 & \\
\hline & SI (L.A. + S.O.) & 0 & & 1 & & 1 & \\
\hline & Total (S.O. + L.A.) & 2 & (1.5) & 4 & $(2.4)$ & 6 & (2) \\
\hline Total & & 22 & (16.9) & 46 & $(27.2)$ & 68 & $(22.8)$ \\
\hline
\end{tabular}

${ }^{1}$ S.O., spina bifida occulta: L; lumbar; S, sacral: L.A., laminal asymmetry.

${ }^{2}$ Numbers in parentheses, percentages. 
Table 2. Lumbo-sacral spina bifida occulta and laminal asymmetry in 178 children with an abdominal pain

\begin{tabular}{|c|c|c|c|c|c|c|}
\hline & \multicolumn{6}{|c|}{ Age $(y r)$} \\
\hline & $\begin{array}{c}1-3 \\
(n=33)\end{array}$ & $\begin{array}{c}3-5 \\
(n=36)\end{array}$ & $\begin{array}{c}5-7 \\
(n=35) \\
\end{array}$ & $\begin{array}{c}7-12 \\
(n=36)\end{array}$ & $\begin{array}{c}12-16 \\
(n=38)\end{array}$ & $\begin{array}{c}\text { Total } \\
(n=178)\end{array}$ \\
\hline S.O.' & 7 & 6 & 10 & 13 & 9 & $45(25.3)$ \\
\hline L.A. & 0 & 2 & 2 & 0 & 2 & $6(3.4)$ \\
\hline S.O. + L.A. & 0 & 0 & 2 & 1 & 0 & $3(1.7)$ \\
\hline \multirow[t]{2}{*}{ Total } & $7(21.2)$ & $8(22.2)$ & $14(40)$ & $14(38.9)$ & $11(28.9)$ & $54(30.3)$ \\
\hline & \multicolumn{4}{|c|}{$X^{2}=3.66$ for 4 d.f. } & \multicolumn{2}{|l|}{ N.S. } \\
\hline
\end{tabular}

\begin{tabular}{|c|c|c|c|}
\hline & \multicolumn{3}{|c|}{ Sex } \\
\hline & $\begin{array}{l}\text { Females } \\
(n=91)\end{array}$ & $\begin{array}{c}\text { Males } \\
(n=87)\end{array}$ & $\begin{array}{c}\text { Total } \\
(n=178)\end{array}$ \\
\hline S.o. & $22(24.2)$ & $23(26.4)$ & $45(25.3)$ \\
\hline L.A. & $4(4.4)$ & $2(2.3)$ & $6(3.4)$ \\
\hline S.O. + L.A. & 1 (1.1) & $2(2.3)$ & $3(1.7)$ \\
\hline \multirow[t]{2}{*}{ Total } & $27(29.7)$ & $27(31.0)$ & $54(30.3)$ \\
\hline & $\mathrm{X}^{2}=0.03$ & N.S. & \\
\hline
\end{tabular}

' S.O., spina bifida occulta; L.A., laminal asymmetry.

Table 3. Parental HLA haplotypes segregation and X-ray examination in sibs of spina bifida cystica-affected subjects

\begin{tabular}{|c|c|c|c|c|c|c|}
\hline Family & Father-A/B & Mother-C/D & $\begin{array}{l}\text { S.B.- } \\
\text { affected } \\
\text { children }\end{array}$ & S.O.-affected sibship & $\begin{array}{l}\text { L.A.-af- } \\
\text { fected sibship }\end{array}$ & Normal children \\
\hline 1 & $2,12 / 30,40$ & $30,5 / 3,7$ & $\mathrm{~A} / \mathrm{C}$ & & & $\mathrm{B} / \mathrm{D}$ \\
\hline 2 & $10, Y / 29,12$ & $2,12 / 2,40$ & $\mathrm{~A} / \mathrm{C}$ & B/D & & $\mathrm{A} / \mathrm{C}^{2} ; \mathrm{B} / \mathrm{C}$ \\
\hline 3 & $19,17 / 19,12$ & $1,17 / 19,40$ & $\mathrm{~A} / \mathrm{C}$ & & & $\mathrm{B} / \mathrm{C}$ \\
\hline 4 & $1,8 / X, Y$ & $1,17 / 3,7$ & $\mathrm{~A} / \mathrm{C}$ & $1,8 / D^{3}$ & & \\
\hline 5 & $29,14 / 29,12$ & $28,40 / 29,12$ & $\mathrm{~A} / \mathrm{C}$ & & & $\mathrm{B} / \mathrm{C} ; \mathrm{B} / \mathrm{D}$ \\
\hline 6 & $10,21 / 3,7$ & $X, 5 / 11,12$ & $\mathrm{~A} / \mathrm{C}$ & $\mathrm{A} / \mathrm{C}^{2} ; \mathrm{A} / \mathrm{D}$ & & \\
\hline 7 & $11, Y / 9,17$ & $3,18 / 29, \mathrm{Y}$ & $\mathrm{A} / \mathrm{C}$ & & & $\mathrm{B} / \mathrm{C}$ \\
\hline 8 & $9,12 / 3,7$ & 9,5 or $27 / 2,5$ or 27 & $\mathrm{~A} / 9,5^{4}$ & $\mathrm{~A} / 9,27^{4}$ & & \\
\hline 9 & $28,5 / 1,13$ & $3, Y / 1,17$ & $\mathrm{~A} / \mathrm{C}$ & B/D & & \\
\hline 10 & $11,22 / 9,12$ & $1,5 / 11,27$ & $\mathrm{~A} / \mathrm{C}$ & B/D & & \\
\hline 11 & $11,8 / 29,12$ & $9,12 / 19,5$ & $\mathrm{~A} / 9,5^{5}$ & $\mathrm{E} / \mathrm{C}^{6}$ & & \\
\hline 12 & $9,7 / 19, \mathrm{Y}$ & $19, Y / 2, Y$ & $\mathrm{~A} / \mathrm{C}$ & & & $E / D^{6}$ \\
\hline 13 & $2,5 / 9,12$ & $2,40 / 9,40$ & $2 \mathrm{~A} / \mathrm{C}$ & $2 \times \mathrm{B} / \mathrm{D} ; \mathrm{E} / \mathrm{D}^{6}$ & & \\
\hline 14 & $1,35 / 26,35$ & 2, Y/X, 27 & $\mathrm{~A} / \mathrm{C}$ & & & $\mathrm{B} / \mathrm{C}$ \\
\hline 15 & $2,18 / 9, Y$ & $X, 18 / 19,14$ & $\mathrm{~A} / \mathrm{C}$ & $2 \times \mathrm{B} / \mathrm{D} ; \mathrm{A} / \mathrm{C}^{2} ; \mathrm{A} / \mathrm{D}$ & $\mathrm{B} / \mathrm{D}$ & \\
\hline 16 & $9,40 / X, Y$ & $\mathrm{X}, 7 / 3, \mathrm{Y}$ & $\mathrm{A} / \mathrm{C}$ & & & $E / C^{6}$ \\
\hline 17 & $9,12 / 9,21$ & $1,7 / 9, Y$ & $\mathrm{~A} / \mathrm{C}$ & $A / D$ & & $B / C$ \\
\hline 18 & $2,13 / 9,18$ & $X, 14 / 29, Y$ & $\mathrm{~A} / \mathrm{C}$ & & & $B / D$ \\
\hline 19 & $9,18 / 19,40$ & $9,8 / 3,35$ & $\mathrm{~A} / \mathrm{C}$ & & & $\mathrm{A} / \mathrm{D}$ \\
\hline 20 & $19,35 / 11,12$ & $11,40 / 19,8$ & $\mathrm{~A} / \mathrm{C}$ & & & $2 \times \mathrm{A} / \mathrm{C}^{2} ; 2 \times \mathrm{B} / \mathrm{C}$ \\
\hline 21 & $2,15 / X, 21$ & $2,12 / 9,21$ & $\mathrm{~A} / \mathrm{C}$ & $\mathrm{B} / \mathrm{C}$ & $\mathrm{B} / \mathrm{C}$ & \\
\hline 22 & $X, 40 / X, 27$ & $2, Y / 1,13$ & $\mathrm{~A} / \mathrm{C}$ & & $A / D$ & \\
\hline 23 & $2,39 / X, 35$ & $1,5 / 2,12$ & $\mathrm{~A} / \mathrm{C}$ & $\mathrm{A} / \mathrm{C}^{2}$ & & $A / D$ \\
\hline 24 & $10,18 / 1,21$ & 2. $12 / 28,12$ & $\mathrm{~A} / \mathrm{C}$ & $\mathrm{E} / \mathrm{C}^{6}$ & $\mathrm{~A} / \mathrm{C}^{2}$ & $\mathrm{~A} / \mathrm{C}^{2}$ \\
\hline 25 & $3, Y / 1,12$ & $19,12 / 3,7$ & $\mathrm{~A} / \mathrm{C}$ & & & $\mathrm{B} / \mathrm{D}$ \\
\hline 26 & $10,18 / 3,7$ & $2,12 / 10,38$ & $\mathrm{~A} / \mathrm{C}$ & $B / D$ & & \\
\hline 27 & $28,12 / \mathrm{X}, 35$ & $3,7 / 1,40$ & $\mathrm{~A} / \mathrm{C}$ & & & $A / D$ \\
\hline 28 & $1,7 / 19,22$ & $2,12 / 2,15$ & $\mathrm{~A} / \mathrm{C}$ & $A / D$ & & $\mathrm{~A} / \mathrm{D}$ \\
\hline 29 & $\mathrm{X}, 21 / 9,12$ & $2,17 / 2,8$ & $\mathrm{~A} / \mathrm{C}$ & & & $\mathrm{B} / \mathrm{D}$ \\
\hline $\begin{array}{l}\text { 'S.B., sp } \\
{ }^{2} \text { Sib HL } \\
{ }^{3} \text { Father' } \\
{ }^{4} \text { Crossin } \\
{ }^{5} \text { Crossin } \\
{ }^{6} \text { Half br }\end{array}$ & $\begin{array}{l}\text { bifida cystica; } S \text {. } \\
\text { dentical to the af } \\
\text { notype undeterm } \\
\text { ver for one child. } \\
\text { ver proved by fas } \\
\text { er or sister. }\end{array}$ & $\begin{array}{l}\text { spina bifida occulta; } \\
\text { ed child. } \\
\text { d for one haplotype. } \\
\text { study. }\end{array}$ & hinal asym & & & \\
\hline
\end{tabular}

There is an independent segregation between vertebral lesions and HLA haplotypes in families of spina bifida cystica cases. This is true for paternal haplotypes $\left(\mathrm{X}^{2}=0.62\right)$ as well as maternal haplotypes $\left(X^{2}=2.1\right)$. Our study is concordant with the data of Bobrow et al. (2) and Kulakowski et al. (6).
An increase in the incidence of HLA-B5 in spina bifida has been described by de Bruyere et al. (3). By combining their data with ours, this increase is significant (11). Pietrzyk et al. (8) have shown an association between HLA-B27 and spina bifida, but in our study, the B27 antigen frequency is lower in patients than in 
Table 4. Lumbo-sacral spina bifida occulta, spina bifida cystica, and laminal asymmetry in spina bifida cystica families

\begin{tabular}{|c|c|c|c|c|c|c|c|c|}
\hline & S.0. ${ }^{1}$ & S.B. & L.A. & $\mathrm{SO}+\mathrm{L} . \mathrm{A}$. & Total & $\mathrm{X}^{2}$ & & $P$ \\
\hline Sibs $(n=49)$ & 20 & 1 & 4 & 1 & $26(53.1)^{2}$ & 8.69 & $<0.01$ & $\begin{array}{l}\text { in comparison with } \\
\text { control children }\end{array}$ \\
\hline $\begin{array}{l}\text { Parents }(n= \\
\text { 74) }\end{array}$ & 13 & 0 & 14 & 8 & $35(47.3)$ & 17.9 & $<0.001$ & \\
\hline $\begin{array}{l}\text { Aunts \& Un- } \\
\text { cles }(n= \\
36)\end{array}$ & 6 & 0 & 6 & 3 & $15(41.7)$ & 6.17 & $<0.02$ & $\begin{array}{l}\text { in comparison with } \\
\text { control adults }\end{array}$ \\
\hline $\begin{array}{l}\text { Grandparents } \\
\quad(n=33)\end{array}$ & 3 & 0 & 5 & 0 & $8(24.2)$ & 0.04 & NS & \\
\hline
\end{tabular}

${ }^{1}$ S.O., spina bifida occulta; S.B., spina bifida cystica; L.A., lamimal asymmetry.

${ }^{2}$ Numbers in parentheses, percentages.

Table 5. HLA antigen frequencies in a population of spina bifida cases as compared to a control population (II)

\begin{tabular}{|c|c|c|c|}
\hline & $\begin{array}{c}\text { S.B. } \\
(n=53)\end{array}$ & $\begin{array}{c}c \\
(n=412)\end{array}$ & $X^{2}$ \\
\hline \multicolumn{4}{|c|}{ Ist locus } \\
\hline Al & 26.4 & 25.7 & \\
\hline A2 & 47.2 & 51.5 & \\
\hline A3 & 13.2 & 19.0 & \\
\hline A9 & 30.2 & 16.7 & $5.11^{2}$ \\
\hline Al0 & 17.0 & 9.5 & 2.7 \\
\hline All & 11.3 & 10.4 & \\
\hline A 19 & 18.9 & 27.7 & \\
\hline A28 & 1.9 & 2.7 & \\
\hline$x$ & 34.0 & 36.7 & \\
\hline \multicolumn{4}{|c|}{ 2nd locus } \\
\hline B5 & 28.3 & 15.0 & $5.43^{3}$ \\
\hline B7 & 13.2 & 23.3 & 2.43 \\
\hline B8 & 11.3 & 14.1 & \\
\hline B 12 & 37.7 & 31.8 & \\
\hline B 13 & 1.9 & 5.1 & \\
\hline B 14 & 3.8 & 11.2 & 2.62 \\
\hline B 15 & 3.8 & 10.2 & 2.14 \\
\hline B17 & 11.3 & 6.8 & \\
\hline B 18 & 11.3 & 8.7 & \\
\hline B21 & 5.7 & 3.9 & \\
\hline B22 & 3.8 & 3.1 & \\
\hline B27 & 3.8 & 11.7 & 2.86 \\
\hline B35 & 15.1 & 10.4 & \\
\hline B40 & 17.0 & 9.2 & 2.94 \\
\hline \multicolumn{4}{|l|}{ B38 } \\
\hline B39 & 1.9 & 1.7 & \\
\hline \multicolumn{4}{|l|}{ B41 } \\
\hline$Y$ & 30.2 & 33.7 & \\
\hline
\end{tabular}

' S.B., spina bifida cystica; C., control.

${ }^{2} P<0.05$.

${ }^{3} 0.01<P<0.02$.

the control population. In their study, affected individuals also exhibit a small increase of HLA-B5.

\section{REFERENCES AND NOTES}

I. Amos. D. B., Ruderman, R., Mendell, N. R., and Johnson, A. H.: Linkage between HLA and spinal development. Transplat. Proc., 7 (Suppl. 1): 93 (1975).

2. Bobrow, M.. Bodmer, J. G., Bodmer, W. F., McDevitt, H. O., Lorber, J., and Swift, P.: The search for a human equivalent of the mouse T-locus. Negative results from a study of HLA types in spina bifida. Tissue Antigens, 5: 234 (1975).

3. de Bruyere, M., Kulakowski, S., Malchaire. J., Delire, M., and Sokal, G.: HLA gene and haplotype frequencies in spina bifida. Population and family studies. Tissue Antigens, 10: 399 (1977).
Table 6. Haplotype distribution in sibships of spina bifida cystica in comparison with lumbo-sacral vertebral abnormalities, spina bifida occulta, and laminal asymmetry

\begin{tabular}{lccc}
\hline & $\begin{array}{c}\text { Sibs } \begin{array}{c}\text { with S.O. } \\
\text { and/or L.A. }\end{array} \\
\text { S.B., }\end{array}$ & $\begin{array}{c}\text { Without } \\
\text { abnormality }\end{array}$ & X $^{2}$ \\
\hline Paternal & 11 & 8 & $X^{2}=0.62$ \\
$a^{2}$ & 11 & 13 & \\
b & 4 & 2 & \\
e & & & \\
Maternal & 9 & 13 & $X^{2}=2.1$ \\
c & 16 & 10 & \\
d & 1 & 0 & \\
f & 16 &
\end{tabular}

'S.O., spina bifida occulta; S.B., spina bifida cystica, L.A., laminal asymmetry.

${ }^{2}$ Other distributions: $a$ and $b$ : paternal haplotypes $c$ and $d:$ maternal haplotypes a and c: propositus haplotypes $\mathrm{e}$ and f: others (exclusion, crossing-over, undetermined).

4. Degos, L., Colombani, J., Chaventre, A., Bengtson, B., and Jacquard, A.: Selective pressure on HLA polymorphism. Nature (Lond.), 249: 62 (1974).

5. Epstein, B. S.: The spine. A radiological text and atlas. Third edition. (Lea and Febiger, Philadelphia, 1969).

6. Kulakowski, S., Delire, M., de Bruyere, M.: Recherche d'une ségrégation des haplotypes HLA dans une étude familiale d'enfants atteints de spina bifida. J. Genet. Hum., 27: 205 (1979).

7. Lorber, J. and Levick, K.: Spina bifida cystica. Incidence of spina bifida occulta Genet. Hum., 27: 205 (1979).

8. Lorber. J. and Levick. K.: Spina bifida cystica. Incidence of spina bifida occulta in parents and in controls. Arch. Dis. Child., 42: 171 (1967).

9. Pietrzyk, J. J and Turowski, G.: Immunogenetic bases of congential malformations: association of HLA-B27 with spina bifida. Pediatr. Res., 13: 879 (1979).

10. Post. R. H.: Pilot study: population differences in the frequency of spina bifida occulta. Eugen. Q., 13: 341 (1966).

11. Richards, I. D. G., McIntosh, H. T., and Sweenie, S.: A genetic study of anencephaly and spina bifida in Glasgow. Dev. Med. Child. Neurol., 14: 626 (1972).

12. Vannier, J. P., Cavelier, B., Lefort, J., Martin, J. P., Rivat, L. and Feingold, J.: $\mathrm{HLA}, \mathrm{Pi}, \mathrm{Gm}$ and $\mathrm{Km}$ phenotypes in a population of spina bifida. Tissue Antigen, 15: 501 (1980)

13. Wynne-Davies, R.: Congenital vertebral anomalies: aetiology and relationship to spina bifida cystica. J. Med. Genet., 12: 280 (1975).

14. D G R S T fellow during this work, 1978

15. The authors are indebted to Professor Borde, paediatric surgeon, who enabled them to carry out this study. We also wish to thank Doctor Gaussin (Le Havre). Doctor Agratina (Vernon), Doctor Belin (Pont-Audemer), and Doctor Petit (Louviers), radiologists. We wish to thank Mrs. Ducimetière for her technical assistance in writing this manuscript.

16. Requests for reprints should be addressed to: J. P. Vannier, Centre Régional de Transfusion Sanguine, Boite postale $N^{\circ} 5,76230$-Bois-Guillaume, France.

17. This research was supported by a Grant from INSERM (ATP $n^{\circ} 36-76-68$ ) (Institut National de la Santé et de la Recherche Médicale).

18. Received for publication December 11, 1979.

19. Accepted for publication October 22, 1980. 